SIR,

\section{0 years of mass-balance measurements along a transect near Kangerlussuaq, central West Greenland}

Volume changes of the Greenland ice sheet are a potentially large contributor to past, current and future sea-level change. One tool needed to obtain a better understanding of the volume changes is direct measurement of the surface mass balance. Ohmura and others (1999) recently summarized the measurements in the accumulation area of the ice sheet, but surprisingly few measurements in the ablation area have been described in the literature. Reeh (1991) and Van de Wal (1996) used and provided references to series of mass-balance measurements from six transects, 1-7 years long. In addition (personal communication from E. Bøggild, 2000), unpublished mass-balance measurements have been carried out along six other transects in the ablation area of the ice sheet and on seven other glaciers in Greenland. None of these series is $>10$ years long.

All of these measurements were performed with sparse stake networks, i.e. the density of stakes per unit surface area was relatively low. The time series obtained at Qamanârssûp sermia $\left(64^{\circ} 30^{\prime} \mathrm{N}, 49^{\circ} 30^{\prime} \mathrm{W}\right)$ was analyzed in detail by Braithwaite and Olesen (1989). Braithwaite and others
(1992) studied the relationship between three mass-balance series from West Greenland and climate. With the established relations, they reconstructed the three mass-balance series for a period of 30 years (1961-90).

In this letter, we present surface mass-balance measurements carried out by members of the Institute for Marine and Atmospheric Research of Utrecht University (IMAU) along the Kangerlussuaq (Søndre Strømfjord, in Danish) transect (K-transect), located on the western part of the Greenland ice sheet along $67^{\circ} \mathrm{N}$. At present, these measurements comprise 10 years (1990-2000), which makes them longer than any other published time series of mass-balance measurements in Greenland. The first 4 years of the measurements were presented by Van de Wal and others (1996). Annual mass-balance profiles for each of the 10 years and the average annual profile for the whole period are plotted in Figure 1. A table of these data can be found on Internet site http://www.magicsclimate.org/.

Visits to the measurement sites have always been made by helicopter. Costs are high and planning is difficult owing to the weather and the limited availability of the helicopters. Therefore, as with the other mass-balance measurements in Greenland, the number of measurement sites is relatively small: six in the ablation area, one near the (10 year mean)

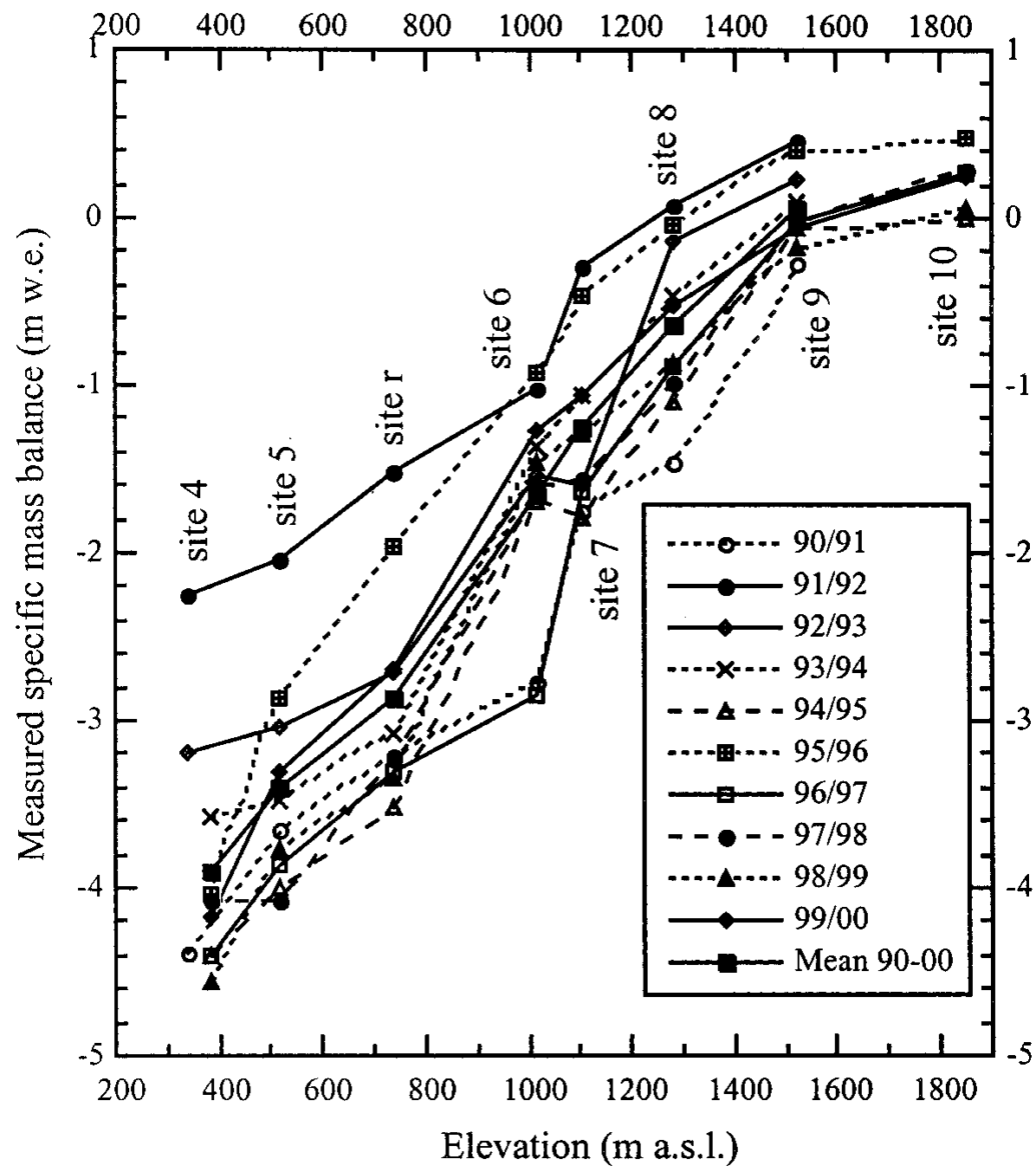

Fig. 1. Annual mass-balance profiles for 1990-2000 and the average annual profile for that period along the K-transect. For the conversion of length changes along stakes to mass balance, we assumed an ice density of $900 \mathrm{~kg} \mathrm{~m}^{-3}$, whereas snow densities were taken from pit measurements. In 1990 the measurements were performed around 21 July; in 1991 around 5 August; in 1992 around 12 August; and from 1993 to 2000 between 19 and 26 August. Balance years until 1993 are therefore longer than a year. Measurements of surface height with acoustic sensors show that ablation has not completely ended at the date of the stake measurements. After 26 August $\sim 20 \mathrm{~cm}$ w.e. of ablation occurs at site 5 (average of 5 years) and $\sim 7 \mathrm{~cm}$ w.e. at site 6 (average of 4 years). 
equilibrium-line altitude (ELA) and one (since 1994) in the accumulation area. At each site at least two stakes have been maintained throughout the entire period. The values presented here (and those on the Internet site) were obtained by averaging the values from the individual stakes. We have not determined the amount of superimposed ice, which is certainly found at the surface just below the transient snowline (the $15 \mathrm{~m}$ ice temperature at $\mathrm{S} 9$ is $-10.0^{\circ} \mathrm{C}$ ). However, whether ice has emerged or is superimposed does not affect the calculation of the mass balance. On the other hand, for the calculation of the annual mass balance above the slush limit (site 10), it matters whether meltwater and rain freeze in the snow below or above the horizon of the previous summer. We have only determined the mass of the snowpack above that horizon, but we did not measure internal accumulation below that horizon. This could affect the calculated mass balance at site 10, because we do not know how deep water penetrates there. This is equivalent to saying that we do not know whether site 10 is located in the wet-snow zone or the percolation zone (see Paterson, 1994).

Owing to the small number of sites, it does not make sense to present the data in the usual way, namely, as averages over elevation bands. Instead, the data are presented per site. The profiles of the individual years are much less smooth than the 10 year mean profile. This may be ascribed to small-scale features like meltwater streams and spatial variations in surface albedo, which cause annual values from individual sites to deviate significantly from the average over a larger area. These small-scale annual effects cancel each other out on a time-scale of 10 years.

The 10 year mean ELA is $\sim 1500$ m a.s.l., which corresponds to the elevation of site 9 . In the ablation area (between sites 4 and 9) the gradient of the mean profile is $3.5 \mathrm{~mm}$ w.e. $\mathrm{m}^{-1}$. Above site 9 the gradient decreases rapidly. Figure 2 shows the interannual variation of the mass balance averaged along the transect, which was computed as the weighted (see figure caption) mean of the values of sites 4-9. The mass-balance anomaly varies between $-370 \mathrm{~mm}$ w.e. for 1996/97 and +640 mm w.e. for 1995/96. In this context, one should bear in mind that the interannual variations in mass

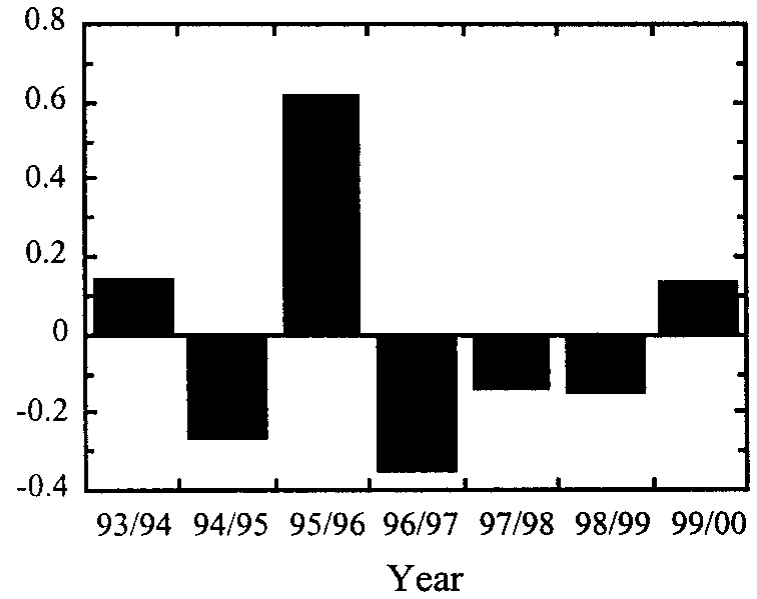

Fig. 2. Annual mass-balance anomaly along the K-transect, averaged for sites 4-9. For calculation of the mean, each site was assigned a weight proportional to the distance along the transect between the two points halfway towards the neighbouring sites. Since the surface slope decreases with elevation, the weight of the sites increases with elevation. The anomaly is taken relative to the mean over the period 1994-2000. The first three balance years were excluded because they were longer than a year. balance are determined mainly by interannual variations in ablation, because of the dryness of the region. The annual amount of accumulation along the K-transect is $\sim 200$ $\mathrm{mm} \mathrm{a}^{-1}$ (Ohmura and others, 1999), and the annual amount of precipitation in Kangerlussuaq is $167 \mathrm{~mm}$ with a standard deviation of $35 \mathrm{~mm}$ (8 years). This variation in precipitation (and accumulation) is small compared to the standard deviation of $330 \mathrm{~mm}$ w.e. in the 7 years of mass-balance measurements along the K-transect plotted in Figure 2. Since ablation, and therefore its interannual variation, decreases with elevation, the interannual variation of the mass balance decreases with elevation, which is typical for Arctic glaciers (Kuhn, 1984).

Greuell and Knap (2000) used the mass-balance data presented in this letter to compare the mean specific mass balance along the transect with the maximum elevation of the slush line as derived from satellite data. Using 8 years of data, they found a significant negative correlation between these two quantities, which suggests that satellite imagery can be used to estimate the surface mass balance.

We plan to continue the mass-balance measurements along the K-transect. Since 1995 they are combined with the operation of automatic weather stations and acoustic height sensors.

\section{ACKNOWLEDGEMENTS}

We would like to thank W. Boot, H. Snellen and other members of the IMAU who helped us during the past 10 years with the collection of the data in the field. We are grateful for the useful comments by R. J. Braithwaite on an earlier version of this letter. During the period 1997-2000 our Greenland project was financed by the Dutch National Research Programme on Global Air Pollution and Climate Change (NOP-II project 013 001236.10).

Institute for Marine and Atmospheric Research, W. GREUELL Utrecht University,

B. DENBY

Princetonplein 5, P.O. Box 80005 ,

3584 CC Utrecht, The Netherlands

R. S.W. VAN DE WAL J. OERLEMANS

\section{February 2001}

\section{REFERENCES}

Braithwaite, R. J. and O. B. Olesen. 1989. Detection of climate signal by inter-stake correlations of annual ablation data, Qamanârssûp sermia, West Greenland. 7. Glaciol., 35(120), 253-259.

Braithwaite, R. J., O. B. Olesen and H. H. Thomsen. 1992. Calculated variations of annual ice ablation at the margin of the Greenland ice sheet, West Greenland, 1961-90. F. Glaciol., 38(129), 266-272.

Greuell,W. and W. H. Knap. 2000. Remote sensing of the albedo and detection of the slush line on the Greenland ice sheet. f. Geophys. Res., 105(D12), $15,567-15,576$.

Kuhn, M. 1984. Mass budget imbalances as criterion for a climatic classification of glaciers. Geogr. Ann., 66A(3), 229-238.

Ohmura, A., P. Calanca, M. Wild and M. Anklin. 1999. Precipitation, accumulation and mass balance of Greenland ice sheet. Z. Gletscherkd. Glazialgeol., 35(1), 1-20.

Paterson, W. S. B. 1994. The physics of glaciers. Third edition. Oxford, etc., Elsevier. Reeh, N. 1991. Parameterization of melt rate and surface temperature on the Greenland ice sheet. Polarforschung, 59(3), 1989, 113-128.

Van de Wal, R.S.W. 1996. Mass-balance modelling of the Greenland ice sheet: a comparison of an energy-balance model and a degree-day model. Ann. Glaciol., 23, 36-45.

Van de Wal, R. S. and 11 others. 1996. Mass balance measurements in the Søndre Strømfjord area in the period 1990-1994. Z. Gletscherkd. Glazialgeol., 31, Part 1, 1995, 57-63. 